\title{
How Strategic Are Strategic Industries? A Network Approach to South Korea's "Big Push"
}

\author{
DUKJIN CHANG \\ Deparment of Socal Studzi, Euba Woman; Unizersity
}

\begin{abstract}
Despite the descult-ling debate surrounding the role of markets and states in

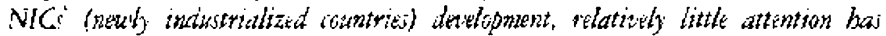
been patid so chefingy the meaning of the term "strategric industries" and systemutically.

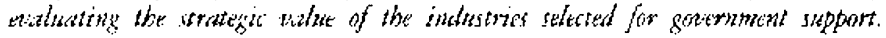

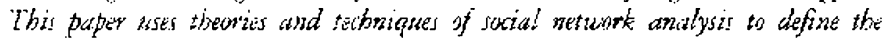
jtratery value of an industry in four different ways: bether export performance.

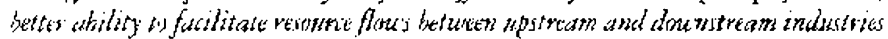

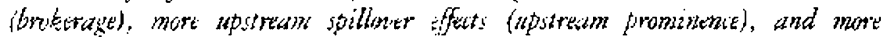

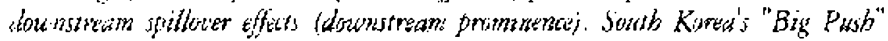

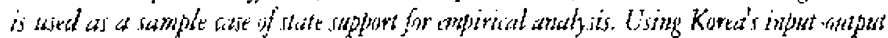
sablis from 1980 to 1990 expst performanie and network vastiables representing inskerage and prominemet thatateristion of an indurtry are calculated and iompared

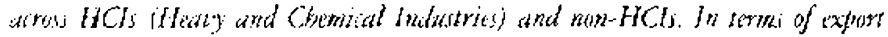

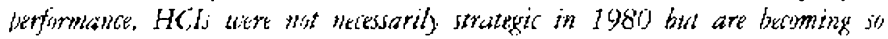

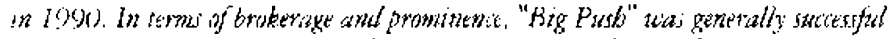

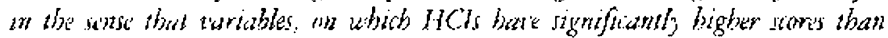

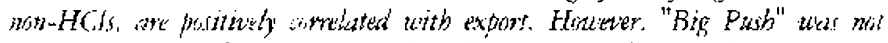

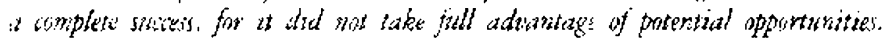

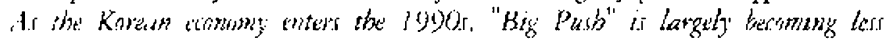
affective than it was in the 10 gits. There are signe that the strategir value

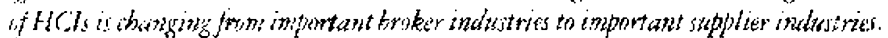

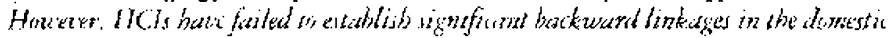

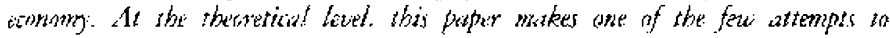

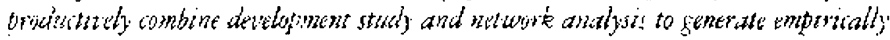
meaninglal risalti.
\end{abstract}

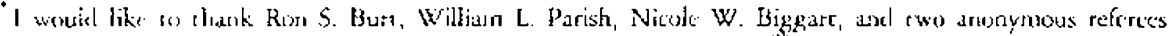
for their helpful commerts. An earlier dratt was presented at the Y.t Annuil Meetitg of the Anjericiln

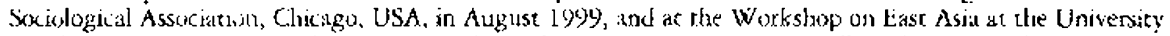
of Chicago. Comments and suggestions from the participants are gratefully acknowledged.

Defect alf corresponkence to Dukin Chang, Fuil-Time Lecturer of Sociology, Deparment of Social Setudies,

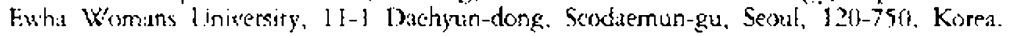




\section{MARKETS, STATES, AND THE "BIG PUSH"}

$\mathrm{O}^{\prime}$ ne of the main debates surrounding the East Asian development has revolved around the role of markets and states. Advocates of marker explanation have stressed that the outward orientation, which is associated with characteristics, such as the neutral incentive regime, positive real interest rates, resource allocation through market mechanism, and exposure to forcign competition, has been the key factor to the East Asian economic success compared to the inward-lowking sttategy of Latin American NICs (Balassa and Associates 1982: World Bank 1993). Howcver, a closer examination of the South Korcan case, one of the key references of the market explanation, reveals that the validity of such an explanation is highly questionable. Balassa's scudy of incentive structures across six scmi-industrial economies denonstrates that the distribution of incentives in Korea, tneasured by effective subsidy fates, is not neutral but balanced between a great amount of positive and negative incencives. Real interest rates on loans remained negative in Korea during the 1970s and 1980s (Park 1994). Resources, most inportantly, financial ones, were never allocared through market mechanism (Woo 1991; Cho and Kin 1995).

Those who emphasize the role of the state in the process of the region's economic develupment argue that the matket-conforming way of state intervention by means of industrial and financial policies has been instrumental Johnson 1982; 1987; LueddeNeurath 1988; Wade 1990). Aside from brodder sociopolitical factors providing the environment with this kind of state intervention, ${ }^{1}$ industrial policy has become che primary research focus. In spite of the heightened inferest in industrial policy, ceviclence supporting effective intervention has largely come from anecdotal case studies of a few industries.2 This lack in systemitic evidence tends to render the whole research program vulnerable to criticisms which advocate that state intervention "has made a leap of faith from the existence of a policy having a certain goal to the achievement of the intended effects" (J)aggard 1990, 14).

Evaluating more systematically the effects of sector-specific industrial policies provides a valuable opportunity to settle the decade-long debate between the cwo theoretical camps and opens up a fresh perspective. The key question here is whether, and in what serse, the so-called, "stratcgic industries" can be considered strategic. Johnson, for example, states that "the heart of [industrial scructure] policy is the selection of the strategic industries to be developed or converted to other lines of work" (1982, 28). In Wadc's "goresned market" theory, one of the crucial ingredients in East Asian economic performance is "more investment in certain key industries than would have occurred in the absence of government intervention" $(1990,26)$. One thing that is less than clear in this argument is how the government planning agency Ministry of Incernational Trade and Industry (MITl) in Japan and Economic Planning Board (EPB) in Korea could be so successful in selecting industries that were "strategic" for national development.

Chalmers Johnsos: points uue the coexustence of authoriearianism ind capitislism in successfui East Asian ceconomies (1987). Wade's term) fir the same sociopolicical environment is at:thuritarian corporatisn ([950). See Leipziger (198) and Leipziger and Pecri (1993) fiss id detailed case scudy of the Korean industria: pulicy. Saxonhouse (1983) hats an ecomomist's counteratgument agatust the cittectiveness of industrial policy. 
Wade suggests that "Lgovernment] leadership is concentrated on industries that are expected to become internationaliy competitive but have not yet become so, and on industries which, though losing competitiveness, the government considers important for the economy's future growth" (1990, 304-5). Although it sounds reasonable, the task may be easier said than donc even for, say, a Nobel economist when it comes to actually selecting thuse strategic industries,

South Korea's "Big Push," or the Heavy and Chemical Industrialization (HCI) Drivc. in the 1970s. provides an excellent research site for adktressing the issue. It is not only one of the best known industrial policy episodes of East Asian development literature, but it also meets virtually all the criceria for being a classical case of industrial policy implementation. Existing literature finds that the Korean state was almost hyperactive in supporting the "Big Push" during the 1970s: real loan tates were set ar acgative lewels to make $\mathrm{HCl}$ finarking cheaper; external borrowings were guaranteed repaymont by the stace-owned banks; ahout half the rotal domestic credit was set aside as policy loans earmarked for HCI industries; special-purposse funds, including the National Investment Fund, were established to meet long-term financing needs (such as equipment purchases); and special-purpose banks and development institutions were founded (Cole and Park 1984: Frieden 1981; Woo 1991; Lee 1991; Cho and Kim 1995; Kim 1997).

The conxistence of this massive state intervention and Korea's continued econonic performance to dace has ofren been taken as evidence for the stare's strategic industrial policy. Some authors contend that the success or failure of the "Big Push" should nor be judged solely on economic grounds because there were extra-economic concerns like the development of the indigenous defense industry (Haggard 19\%; Wo0 1991). However, this still leaves the guestion unanswered lxcause the fact that a certain industrial policy had extra-cenomic purposes does not explain how it led to impressive economic performances. Whether or not there werc extrit-economic concerns, were those industries selected as the strategic ones strategic in the context of the national economy? If so, in what sense wert they strategic?

This paper attempts to answer these questions by suggesting different meanings of an industry's strategic value in the national economy and examining the actual effects of South Korea's "Big Push" according to the various senses of strategic value. The theory and techniepues of social nerwork analysis are applied to Korca's input-output tables in 1980 and 1990 . Network theory suggests two brod classes of varjables representing the strategic position in a network of inter-industry transactions: centrality, or prominence on the one hand; and range or brokerage on the other. If the industries selected for HCl wetc, in fact, strategic, it is expected that they show, on average, significantly higher scores on these variables than the other industries. Another concern is whether the industrics with high values on these variables contribute significantly more to export. it is widdy recognizad that relative export sizc is strongly and positively correlated with GNP growth (Michaely 1977). Just like organizations and people performing better when occupying strategic positions in the networks to which they belong (Burt 1992),

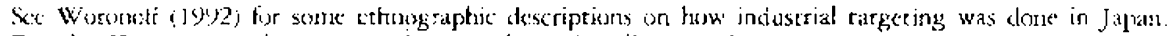
For the Korcan case, Jowever, such esearch is vircually nonexistent, 
one can reasonably expect strategically located industries in the national economy to petform beter by exporting more.

Section II explains the different meanings of an industry's strategic value in the national economy, Section III describes the data. Section IV provides topological maps of Kortan markets in 1980 and 1990 , giving some visual sense to the relative possitions of HCI industries in the overall structure of the Korean economy. Section $V$ compares HCl and non-HCI industries across various network variables. Section Vl examines the network analysis results at the level of the individual industries, followed by the conclusion.

\section{VARIOUS MEANINGS OF STRATEGIC INDUSTRIES}

\section{Export and Spillower}

In East Asian development literature, one obvious meaning of the term "strategic" is directly linked to good export performance. In an economy following the so-called, "export-led-growth trajectory" (Haggard 1990), no other criteria can be more compelling in selecting strategic industries than export performance. For instance, confronting conomists' claim that HCIs returncd only meager rusults and, therefore, "Big Push" is a classic illustration of the follies of excessive statc intervention, Wade argues that medium-term resules are much better than short-term results as can the seen by the face that by 1984, sixty percent of Korea's export came from HCIs (1990, 319-20).

There are, however, ways in which a certain industry can be strategic for the development of the national economy even if it does not generate a great amount of export. An industry may be highly scrategic in the sense that without its proper development, other upstream or downstream industries citunot perform as well (i.e., through positive spillover effects). This idea is also wellacknowledged in the East Asian development literature in statemenrs like, "fin a plan rarional stake\} the government will give grearest precedence to industrial policy, that is, to a concern with the structure of domesic industry and with promoring the structure that enhances the nation's international competitiveness" (Johnson 1982, 19) and "sequential externalities occur where a large upstream plant would, if buile, induce the entry of downstream firms to make wse of new profit opportunitios stated by the upstream firm but not appropriable by it" (Wade $1990,353)$.

Vot all industries are equally qualifted to make comparable degrees of positive spillovers. For the most part, the potential amount of positive spillover an industry can produce - hence its strategic value - is a tunction of its position in the network of inter-industry transactions. Network theory offers two broad classes of the strategic position concept. One is range and brokerage. The other is prominence.

\section{Range and Brokerage}

Seven variables measuring an industry's transaction range and trokerage potential are 
of interest. An industry with a broad range of transactions with many other industries is strategic in that the pusitive spillover from this indzstry can affect many others. An industry which brokers transartion among many other industries is also strategic bxcause, without the proper development of this indusery, potential profit opportinities in orher industries that noed brokerage cannot materializc. Despite their strategic importance from the perspective of the nacional economy, these industries may not be profitable enough or may be no risky. Therefore, the private businesses ane not willing to invest in these industries without govermmen support. Variables measuring this chatacteristic of an industry are as tollows:

1. ego-network size: A number of industries that directly transact with (i.e., sell to or buy from the industry under consideration.

2. effective size of egu-network: Ego-network size may overestimate an industry's spillover potencial if many of its alter indestrics have transiction tits among themselves. Effective size of ego-network climinates this redundant portion from the ego-network size.

3. contact efficiency: An industry may make positive spillovers more efficiently by having more nonredundant transaction cies relative tot its total transaction ties. Contact efficiency is nonredundant conteacts divided by the cotal number of contacts.

4. alter network dersity: If the alter industrics are densely networked among chemselves, it is likely that the cgo-industry is just another member of the clique ather than being in is strategic position. Alter network density is the average marginal scrength of relations berween an ego-industry's contacts.

5. proportional density of alter network: Alter network density is affected by the stength of tics. However, it is pessible that the proprortion, rather than the strength, of altet network density is more important. Proportional density of alter network is the proportion of contact pairs that has some kind of connection with one another. In a network of contacts all connected by weak relations, alter network density is low and proportional density is high.

6. network constraint: An industry is strategrically disadvantaged if it is highly constrained by its transaction network. Constraint comes from having an alter industry with exclusive relations along with ego-industry's other alters and there being no substitutes for the alter. The sum of this dyadic constraint across alter industrjes is the aggregate constraint on ego-indastry.

7. hierarchy: $\Lambda$ constrained industry is more severely disadvantaged if its network constraint is concentrated in the hands of a dominant alter industry. Hiecarchy describes the distribution of constraint actoss transaction relations

\section{Promineuce}

Prominence and centrality measures have often been used to identify the "most important" actors which are, by definition, located in strategic locations within a nerwork (Wasserman and Fast 1994, 169). Characteristics associated with actors who are central, or prominent, are prestige, visibility, power, and more demand from ochers in the network for their 
network time and energy (Knoke and Burt 1983). An actor which is the object of relations has something of interest to everyone sending the relations, which makes him prominent and thereby, more jowerful (Schot 199) ], 188). In the context of inter-industry transaction network, an industry is considered highly strategic when its proxducts are needed for production in many other industries (downstream; forward linkage effect) or it purchases a great deal from many other industries (upstream; hackward linkage affect). Prominence is measured at different levels of sophistication as explained below."

1. choice status: This is the number of industries that reach the ego divided by the number that could have done so

2. extensive relations prominence: If two industrics receive transaction ties from the same number of alter industries, the one receiving stronger ties is more prominent. Extensive relations prominence is obtained by weighing choice status relations with cheir strength.

3. exclusive relations prominence: In a densely connected netwotk of transactions, it can be difficult to distinguish top from bottom of the structure because every industry receives about the same number and strength of ties. Exclusive relations prominence measures the extent to which the ego-inulustry is the object of exchuse rctarions from every other industry:

4. power: Power comes from being the object of exclusive relations from alters which are also powerful themselves. An industry is powerful in the inter-industry transaction network if it receives many strong and exclusive transaction ties from other powerful industries.

Now there are at least three different ways for an industry to become strategic for the development of the national economy. The simplest and mose obvious way is by exporting a greac deal of its products. A second way is by brokering many transactions between other industrics. A third way of being strategic is by being prominent. The rest of this paper demonstrates the ways in which these three senses of the rerm HCls can be said to be strategic by analyzing Korea's input-ourpuc tables in 1980 and 1990.

\section{INPUT-OUTPUT TABLES AND THE IDEN'TIFICATION OI" "BIG PUSH" INDUSTRIES}

In this paper, data for analysis come from Korea's input-output tables evaluated at producers' prices in 1980 and 1990 . The year 1980 is an obvious choice for analysis because the "Big Push," launched in 1973. came to an official end in 1979 with the announcenent of the Economic Stabilization Policy. The year 1990 is also chosen for analysis because, as in W'ade's argument quoted earliex in this paper, there may be some time lag before the effects of inderstrial policy can matcrialize. In addition, existing research suggests that the positive association berween export and economic growth is 
conditioned by world-market situations (Kavoussi 1985; Singer and Gray 1988). Korea experienced a major turnaround toward favorable world market situations in 1986 thanks (1) the so-called, "three lows,"6 adding more pussibility for the HCI policy to show its effects in the late 1980 s (captured in the 1990 table).

The official definition of HCIs, as laid out in the plan, includes six three-digit SIC industries: industrial chemicals; other chemicals; petroleum and coal products; iton and steel; nonferrous metals; and machinery. Hecause SIC has a slightly different classification scherne from the input-output table, the cwo schemes are compared (industry by industry) to determine which input-cutput scctors belong to the above six SIC industrics. Fifreen of the sixty-four input-output sectors in 1980 and twenty-one of the seventy-five input-output scctors in 1990 correspond to the HCls as summarized in Table: 1.

TABLF 1. INPL.TALTPL:T SECTORS CORRESPONDING TO HCIS, 1980 AND 1990

\begin{tabular}{|c|c|c|}
\hline SIC lndustry & 1980 I-O Sectors & 1990 I-O Secrofs \\
\hline \multirow[t]{3}{*}{ industrial chemicals } & basic shemical products & $\begin{array}{l}\text { Percochemical basic products and } \\
\text { incermediate chemical products } \\
\text { (oryanic chemical) }\end{array}$ \\
\hline & & Inorganic chemical hasic ptoducts \\
\hline & $\begin{array}{l}\text { plastic material and synthetic nubber } \\
\text { chemical fibers }\end{array}$ & $\begin{array}{l}\text { Plastic material and syrthetic rubber } \\
\text { Chetnical fithers }\end{array}$ \\
\hline \multirow[t]{3}{*}{ other chemicals } & $\begin{array}{l}\text { chemical ferrilizers and agricultural } \\
\text { chemicials }\end{array}$ & $\begin{array}{l}\text { Chemical fertilizers and agricultural } \\
\text { chemicals }\end{array}$ \\
\hline & drugs, cosmetics, and soap & Drugs, cosmerics, and sonp \\
\hline & miscellaneous chemical products & Miscellaneous chenical products \\
\hline $\begin{array}{l}\text { petroleum and coal } \\
\text { proulucts }\end{array}$ & pctroleum refinery products & Pectoleum refisery products \\
\hline ien and steel & $\begin{array}{l}\text { pigs irno and steel } \\
\text { primary irou and steel products }\end{array}$ & $\begin{array}{l}\text { pig iron and crude secel } \\
\text { Primary iron and stcel products }\end{array}$ \\
\hline nonferrous metals & $\begin{array}{l}\text { nonferrous metal ingots and primary } \\
\text { nunferrous metal products }\end{array}$ & $\begin{array}{l}\text { Vonferrous metal ingors and primary } \\
\text { nonferrous metal products }\end{array}$ \\
\hline \multirow[t]{9}{*}{ machinery } & $\begin{array}{l}\text { fatricaced metal protucts } \\
\text { general machinery }\end{array}$ & $\begin{array}{l}\text { Fabricared metal protucts } \\
\text { Genera! industrial machinery and } \\
\text { equipment }\end{array}$ \\
\hline & & Special industrial machisery and cyuipment \\
\hline & clectrical machines? & Fíectrisal machines, cquicment, and supplies \\
\hline & electronic and communications equipment & Household electric and electronic appliances \\
\hline & & Communications equipment \\
\hline & & Electronic components and accessories \\
\hline & & Computer and office equipmear. \\
\hline & transportation equiprtent & Motor vehicles \\
\hline & & $\begin{array}{l}\text { Shipbuilding and other transportation } \\
\text { equipsment }\end{array}$ \\
\hline
\end{tabular}

\footnotetext{
- Bank of Korca (1991) is folkwed for English-translarion of sectue definitions.
} 


\section{MARKET BOUNDARIES AND "BIG PUSH" INDUSTRIES}

Spacial maps of the Korean markets in 1980 and 1990 are gencrated in Figure 1 and Figure 2 to show the market boundaries and relative locations of HCIs. These are very close replications of the maps produced by Burt (1988) and Burt and Carlon (1989) in that the two sextors are close together in the map, so close that they involve identical purchase relations from each other (like that of a supplier market with its identical sales telations).? In Figure 1 and Figure 2, cach dot represents an input-output sectur classified by the Bank of Korca. IHCIs are rnarked with solid dots so that they can be easily distinguished from the hollow ones, which are the non-HCIs.

In both figures, the main orientation of the map is given by the flow of the factor input secrors located in the east to the final demand sectors of the west. Reading the maps from right to lett, one begins with factor input and then moves on to the industries with a long chain of forward linkage effects, such as mining, synthetic materials, chennical proxtucts, service induscrics which should be close to every other sector, consumer gonts and heavy industries which sell disectly to provate houscholds and foreign markets, and final demand secturs.

Note that final demand secors are very different from each other while the factor input sectors are closely tied together. Three things are worth mentioning with regard to the final demand sectors. First, government demand sectors - govemment fixed capital

The'se are very close, but nut exikt, replications due to ditferent theoretical as well as ecchnical considerations when mplaining different economies. First, exogemous secross are inchuded in these figures. Fexogenous sectors indude four factor inpue (or vaiue-idded) and six final demand sectors. Factor inpult sectors are

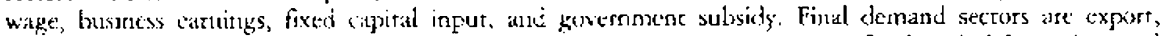
incretses in insenrory. privatte consumption, govesnment consusnption, privare fixed capital focmation, and

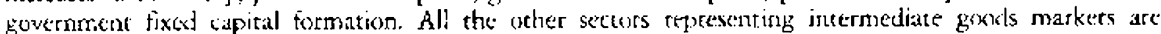
called "endogrenons" or "intermediare" seeters. The table size usually referted to as .NXN rable indicates the lumber of chest endogenolis secours. Like in any ocher nerwork analysis tasks, andyzing input-output

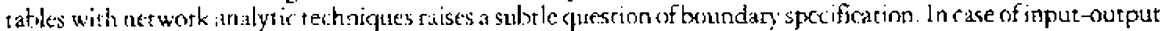
tahles, the majur tecision is whether to include exogenous sectors in calculating network variables. There are trakle-effs in gring sither way. I hose to include exogrenous sectors betause uf three reasons: (1)

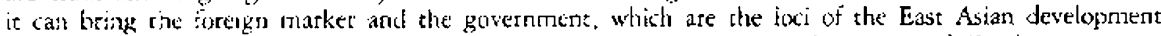

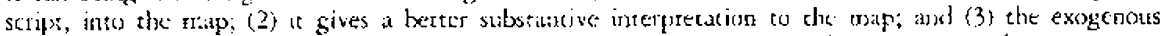
secters being exrluded ltom the analysis, the market paraneters are nore ambignus. Hy market patameters

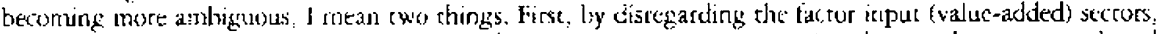
crossuchlumn comprarisons (i.c. comparisons of infit stuciure across sectors) and network parameters based on them become anbigitros. Second. by disregateding the tinal demand sectors. cross-tow comparisons

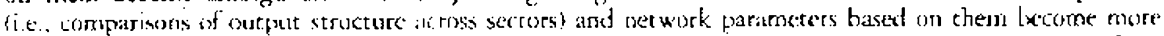
ambigunus. Is is hasct to incerpret, for example, the market constraint impused on sector A coming from buyet sector $B$ when cigley percent or murt of secter $A$ 's outpur is sold in the foreign markets, which is actually the case with dajey, rextile and apparel, ectronit and telecommunications equipment industrics in 1980. The dowresite tor including exogenows sectors is that one has to treat them as if they wete industries. but this is simply now true. However, thete has in be more gains than losses by indekding

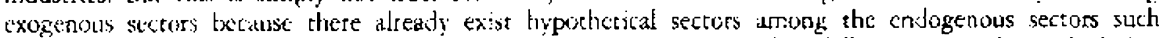

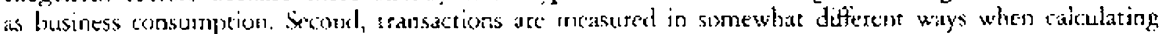
structural equivalence bior generating the maps. Preceding studies tenort that specialized markets are obt:ined

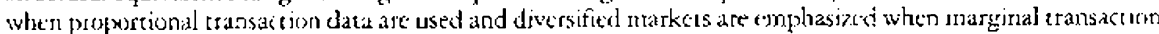

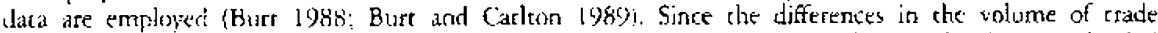

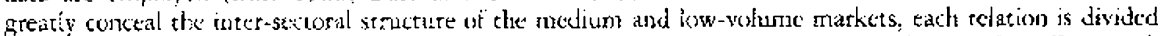
by dhe startiatel deviation of the corresponding sector's relations. This trearment has similar effects aith dividing (ac)/2 relation with the maximum strength cclation of the sorresponding sector th the sense that

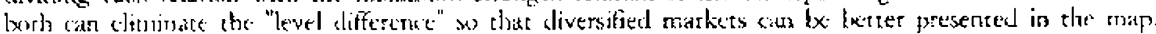




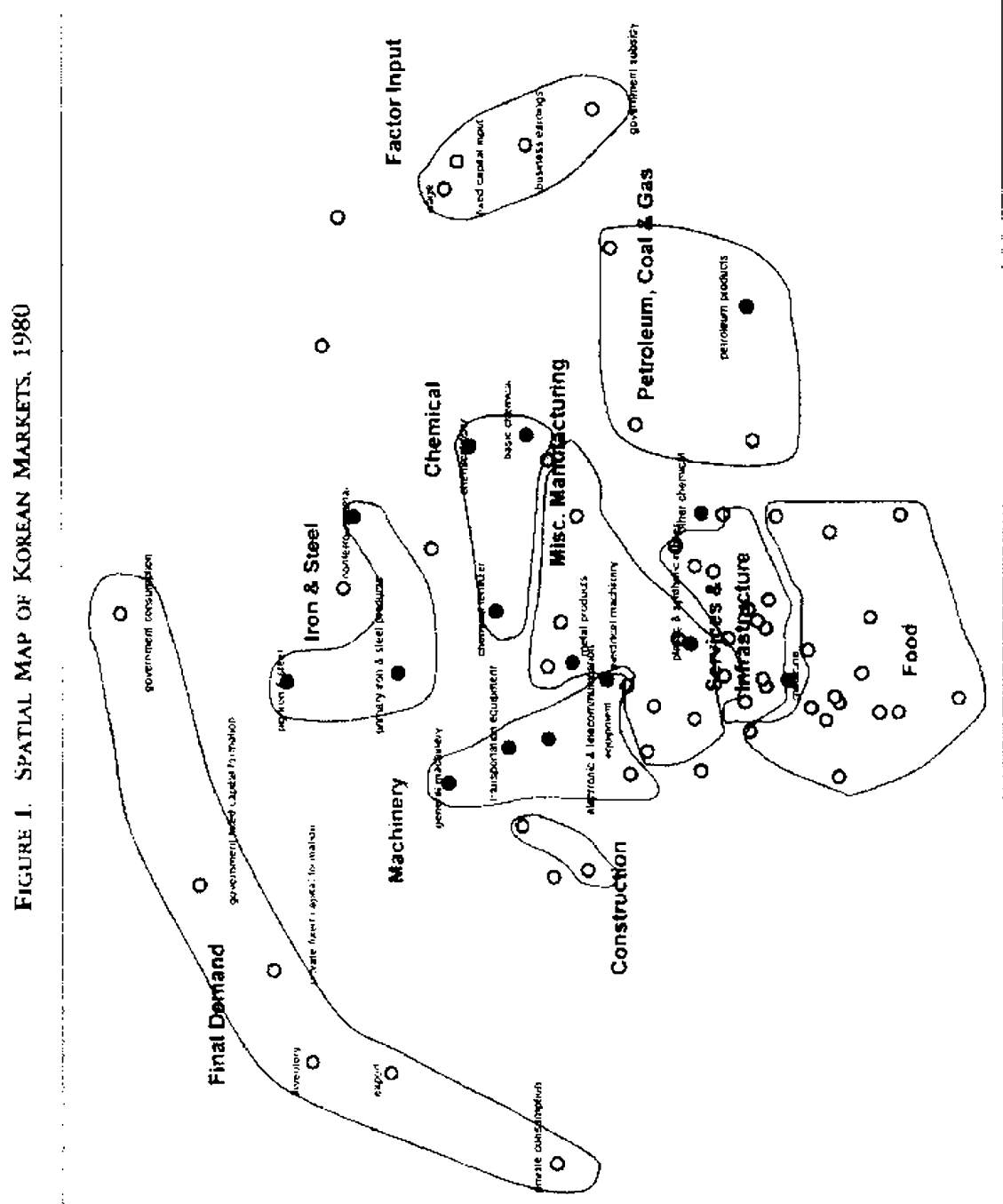




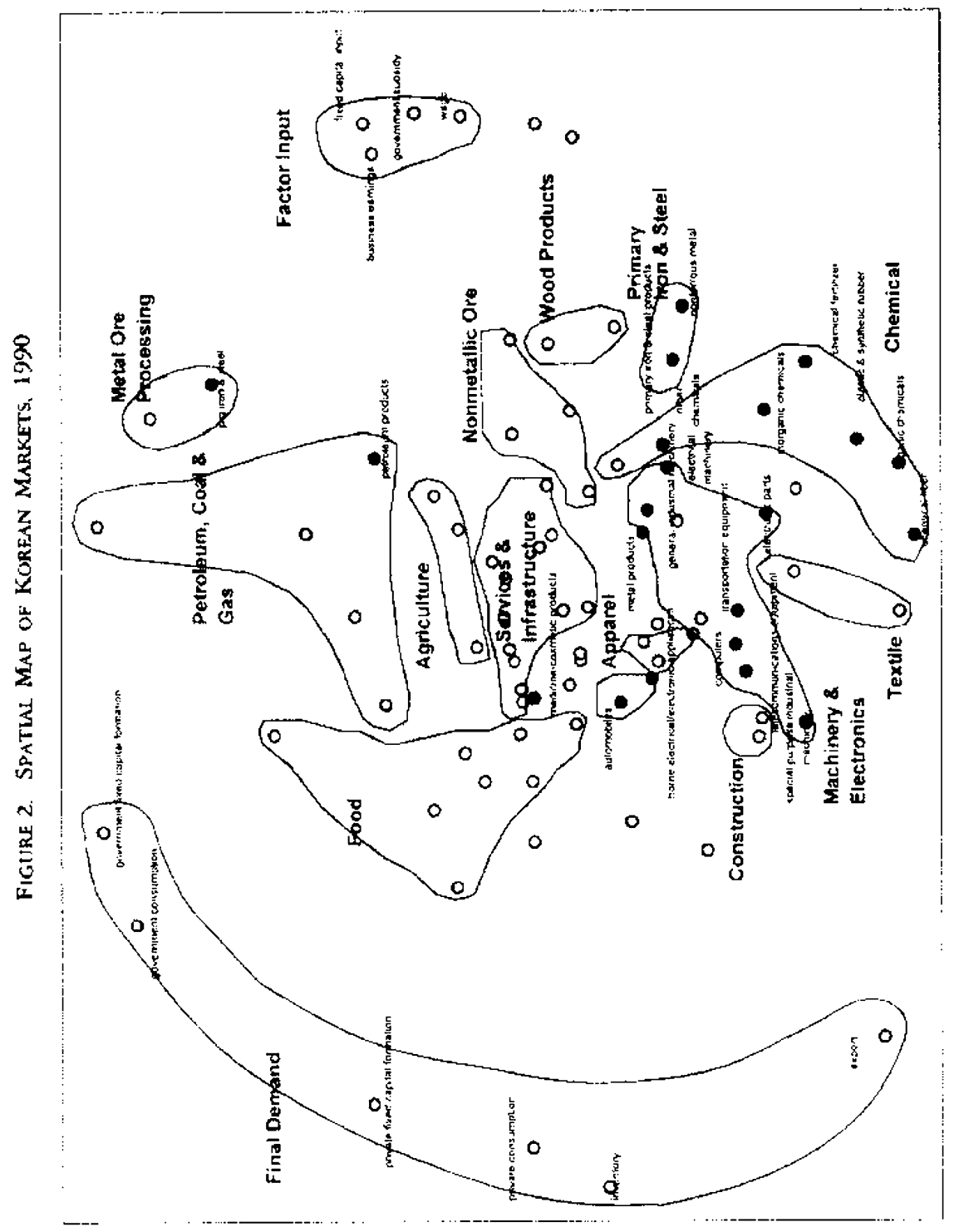


formation and government consumption - are segregared toward the nurthern boundary of the economy, whereas the private demand sectors - private fixed capital formation and private consumption - are located in the middle. Because government demand sectors, like other final demand sectors, do not selt their output to any other sectors, they are located on the west side of the map. They are pushed toward the northern boundary because, unlike private demand sectors, they purchase little from only a small number of industries. In 1980, for example, the combined amount of purchases by the two government dernand sectors accounted for only $7.38 \%$ of the total output, whereas the two private demand secturs purchased some $36.45 \%$ of it. Moreover, only seventeen of the sixty-four intermediate sectors sold their output to one or both of the government demand sectors in the same year, while fifty-five of the sixty-four intermediate sectors sold their output $\mathrm{t}(\mathrm{)}$ private demand sectors. This indicates thar government demand sectors and sectors adjacent to them should have relatively little upstream or backward linkage effects. $\%$ Second, compared to the government demand sectors, private demand sectors are understandably closer to the consumer goods markets (such as fool, apparch, and home appliances). Third, the export sector is close to machinery and textile industries, reflecting the face that these are the major players in the markets abroad.

The vertical axis of the map gives a tour from old to new technologies (from south to north in 1980; from north wo surch in 1990). Alternatively, it can be seen as moving from the primary industries which collect resources directly from nature (e.g., mining market and agricultural products market) to the secondary and tertiary industries (e.g., machinery and chemical). This orientation of (he vertical axis is the same as reported ly existing literature for the American markets (Burt 1988; Burt and Carton 1989). In 1990, the southern half of the map could be further divided into southeast and southwest quadrants. The southeast quadrant is populated with chemical industties and the southwest quadrant by heavy machinery and electronics. This detailed division was

\footnotetext{
A There are essentially two ways sector a can be located close to sector $j$ in the map. Strwcturai ropuralence as Euclidean distance used for generating Figure 1 and Figure? is defined by the following ecquarion:

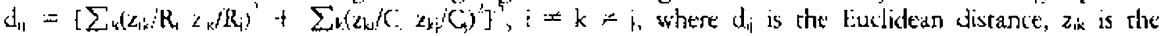
amount of sales in millions of Korean won from input-rustput seceor $;$ so sector $k$. and $R_{i}$ and $C_{\text {. }}$ represent standard deviations o; $i$-th row and ath criumn, respectively. Let us say in this case that sector is

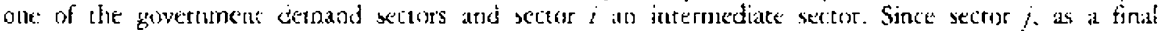
demand sector, dies int sell its ourpus to any other sectors, the $z_{i k}$ ietm in the structural equivalente equation should al ways be zero. Thus meats that an iutermediats sector $i$ is slose to sector $j$ to the extent. that the $z_{k}$ rem is also ilose to zero. Therefore, sector $i$ can be clise ro sector $j$ to the extent that it selis a large propertion of its output to the zosernment demand sector $j$. Once obvious example of this mechanism is the heary construction inctustry in 1980 and 1 (X)0. In 1990. for exarmple, the industry sold its riszpit ro only four orhet secicts which are "public admitistration and defense," "private fixed

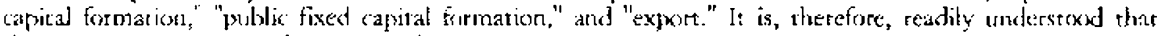
the induscry is close tis final temand sectors. Another way in which sector $i$ can be ciase to sector $i$ is by sertor is having a similar purchase transactions profile to that of sector $j$, adjusted for the standard deviation of each indistry. This characteriste puts secror $i$ close ro secror, by making the second term of cte structural zquivalerice equition slose to zero. An exarnple of this second inchianism is "crude petroleum and natural "as" in 1990. which were purchased from no other industries. A similat reasoning can be applied to factor input sectors. Since they do not purchase outputs from any other sectors, the $z_{k_{j}}$ term

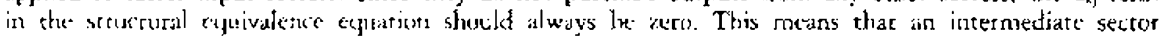
$\therefore$ is close to a bacroe input secter $j$ to the extent that $z_{\mathrm{ki}}$ term is also chise to zetio. Therefore, intermediate sectess tha panchase it large monportion of their input from the factor input sectors are located toward the east side of the map. Also, incisuscies with similar jales cransactions profile to chat of factot input sectors are also clise to them in the nap.
} 
less clear in 1980 , although there were some distinction between chemical industries in the northeast quadrant and heavy industries (irorl and steel; machinery) in the northwest quadranc.

Another interesting observation is that much finer market boundaries can be defined in 1990 relative to the 1980 result: "iron and steel" market is further divided into "metal ore processing" and "primary iron and steel"; "miscetlaneous manufacturing" into "appard," "textile," and "wood products"; and "machinery" matker into "machinery and cleceronics," and "autos and bomc appliances." Market boundarics will be better defined as the economy matures.

Now let us curn to the location and distribution of HCls. In both research years, HCIs belong to the "newer technology" half of the map (norehern half in 1980; southern half in 1990). In terms of their distribution, one can set that HCIs are somewhat more clustered together in 1990 than they were in 1980. Considering that in both maps industries are clustered toggether to the extent that they have an idenrical purchase and sales profile, this change suggests that by 1990 , HCls will have come to share more similar transaction patterns than they did in 1980 . Remarkable changes are observed in the relative locations of some broadly defined $\mathrm{HCl}$ markets, such as "primary iron and steet" (from west to east) and "chemical" (fron around the concer to cast). This kirel of change is also observed in wome non-IICI markets, such as "ford" (from around the middle to west) and "petroleum, coal, and gas" (from east to the mideilc). To the extent that the relative locations of industries in the maps are decermined by the structural equivalence among them (explained in cletail in footnote 7), industries moving toward the west (such as "food") are expected to lave increasing upstrearn spillover effects and decteasing downstrean spillover effeces. Inclustrits movirng toward the east (such as "primary iron and stecl" and "chemical") are expected to bave increasing downstream spillower effects and decreasing upstream spillover effects. Industries located around the center may have higher brokerage potential. Still another finding is that HCIs are more or less widely scartered in the economy rather than concentraced around a certain sector (e.g.. around the expore sector). This suggests that a relatively wider variety of industries was schected as HCIs than the term "strategic" sometimes implies.

\section{HEAVY AND CHEMICAL INDUSTRJES, STRATEGIC NETWORK POSITIONS, AND EXPORT}

I begin by comparing the average export amount of HCIs with non-HCls. Descriptive statistics and ANOVA tables are summarized in Table 2. In borh research years, $\mathrm{KCI}$ have exported mote on average than non-HCls. However, the difference was far from significant in 1980. Although the p-value is srill slightly above the conventional level of .05 in 1990, it seems obvious that the clifference in export amount between HCls and non-HCls has become much more distinguished in 1990 than in 1980, supporting Wade's argamenc that medium-term results of "Big Push" are much better than short-tem results. If we use expors anount as the cricerion of stratcgic industrits, there is not enough evidence in say that HCls were strategic in 1980 . 
TABt.F 2. AVtRAGE EXPORT OF HCIS VS. NON-HCIS IN 1980 AND 1990: DESCRIPJNe STAJISTICS A.VD ANOV.A TABLF

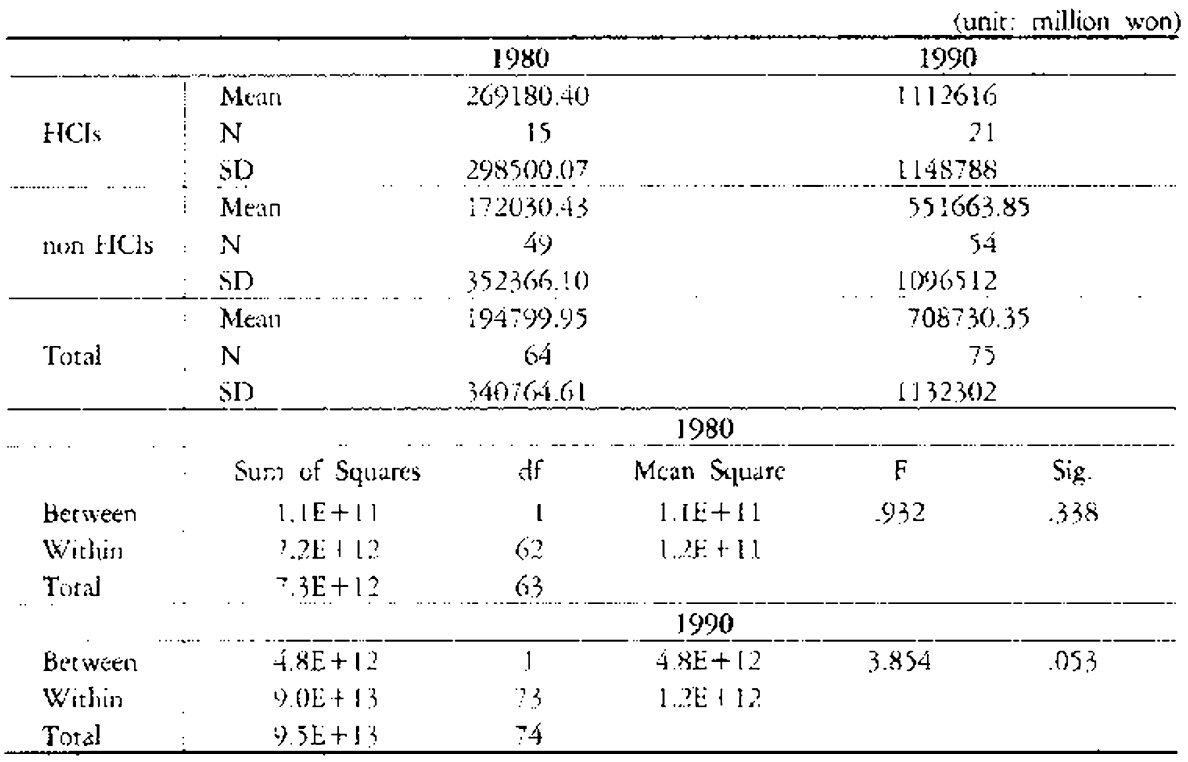

Table 3 shows whether HCIs are on average ligher or lower than non-l ICIs on various nersork variables, and the correlation coefficients of these variables with export amount. It is remarkable that many of the network variables which represent different meanings of the strutegic position in inter-industry transactions are systematically correlated with export. As explained earlier in this paper, there are seven variables capturing range and brokerage potential of an industry for both 1980 and 1990 . Since prominence is a dircctional concept," the four prominence variables are turther divided into upstream and downstream variables, increasing the number of variables to cight for each year.

The variable most strongly correlated with export is extensive relations prominence in both years $1.499^{* *}$ in $1980 ; .329^{* * *}$ in 1990). Note, however, that the direction of spillover effect is reversed in the ten-year period from upstean to downstream, which means that the extensive relations prominence industrics as buyces were exporing more in 1980 and extensive retations prominconce industrics as sellers are now exporting more in 1990 . This reversal of direction also holds for exclusive relations prominence. It seerns that receiving exclusive cransaction tics from orher industrics matters less than receiving extensive transaction ties in terms of contributing to export, as can be seen by the fact that corrdacion coefficients with an cxport for exclusive relarions prominence variables

\footnotetext{
"For : i diectimal wework variable, the meaning of incorsing ties is ditferent from that of outguing sies. likewise, buyiag trum in adjacent industry :s different from selling to she same industry. In the ordinaty

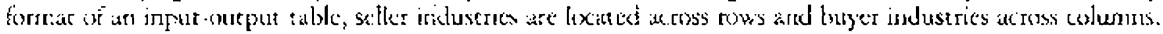

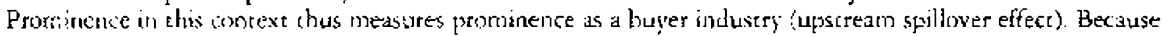

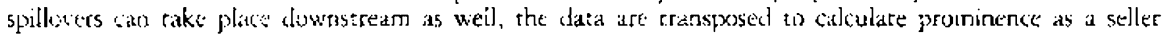
induse of edowsteirn spillower effect).
} 
Tahi: 3. Nejwork Characteristics of Hois and EXport Performance

\begin{tabular}{|c|c|c|c|c|}
\hline & \multicolumn{4}{|c|}{1980} \\
\hline & Mean HCI & $p^{p}$ & Corr. with Export & $p$ \\
\hline ego-network size & $\mathrm{H}^{\circ}$ & .081 & $.365^{* 23}$ & .003 \\
\hline effective egt-nccwork size & $H^{n * \cdots}$ & .006 & $.273^{2 x}$ & .029 \\
\hline contact efficiency & $\mathrm{H}^{*+*}$ & .006 & -.140 & .270 \\
\hline alter network density & 1. & .064 & $-.214^{*}$ & .090 \\
\hline alter network proyortional densigy & I & $2 \% 5$ & $-.37)^{*+\infty}$ & .002 \\
\hline network constraitıt & $I_{.}^{*}$ & 050 & $-.213^{*}$ & .092 \\
\hline hierarchy & $\iota^{*}$ & .031 & -.195 & .123 \\
\hline choice sratus (upstream) & $\mathrm{H}^{*}$ & .084 & $.239^{\circ}$ & .057 \\
\hline choke status (dowistream) & $H^{*}$ & $.06 x i$ & $.338^{* *}$ & .006 \\
\hline extensive relations prominence (upstream) & $\mathrm{H}$ & .800 & $.499^{k+1}$ & $(9)$ \\
\hline extensive relations prominence (downstrcam) & $\mathrm{H}^{*}$ & .030 & $.300^{* *}$ & .016 \\
\hline exchusive relations prominence (upstrcam) & $\mathrm{H}$ & .832 & $427^{* * *}$ & .000 \\
\hline exclusive relations prominente (downstream) & $\mathrm{H}^{\circ}$ & .083 & .123 & .332 \\
\hline power (upstream) & $L$ & .428 & $.325^{\cdots}$ & .009 \\
\hline \multirow[t]{2}{*}{ pxwer (dow:ascreann) } & $\$ 1$ & 435 & $-.02 ?$ & .835 \\
\hline & \multicolumn{4}{|c|}{1990} \\
\hline ego-netwoth size & $H^{*}$ & .093 & $.263^{n+}$ & .023 \\
\hline effective egu-nctwork sias & $\mathrm{H}^{* *}$ & $.0 ! 9$ & .149 & .201 \\
\hline contact efficiency & $\mathrm{H}^{*}$ & .048 & $-.306^{* *}$ & .008 \\
\hline alter netwerk density & $\mathrm{L}^{\prime}$ & .088 & 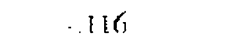 & 320 \\
\hline alter network proportional density & $i^{2}$ & .082 & $-.303^{* *}$ & .008 \\
\hline network constraint & $\mathrm{L}$ & .145 & -.167 & .153 \\
\hline hicrsirchy & L & .182 & -.076 & .519 \\
\hline chorice status (upstream) & $\mathrm{H}$ & .122 & $.221^{\circ}$ & $.05 ?$ \\
\hline choict stacus (downstream) & $\mathrm{H}^{* *}$ & .021 & $.301^{\circ \cdots}$ & .009 \\
\hline extensive relations permenchee (upstream) & $H$ & .696 & $.2488^{*}$ & .032 \\
\hline extensive relations prominerice (downstream) & $\mathrm{H}$ & .222 & $.329^{-* *}$ & .0194 \\
\hline exclusive relations prominence (upstream) & $\mathrm{H}$ & .926 & .170 & .146 \\
\hline exclusive relatrons pruntinence fdownstreami & $\mathrm{H}$ & .467 & $.196^{\circ}$ & .093 \\
\hline power (upsist:an) & 1. & .340 & .138 & .237 \\
\hline power (dowristre;n) & L. & .537 & -.073 & .532 \\
\hline
\end{tabular}

a) Hi: HCIs are me average highe? than non-kHCJs; L: HCIs are on average lower than nom-HCls.

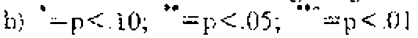

c) Detarled descriptive seatistics and ANOVA tables are available from the suthot uprn tequest.

are systematically smaller than the corresponding coefficients for extensive relations prominence variables. Power, which comes from receiving exclusive relations from other industries who thenselves are also powerfial, natters even less than exclusive relations prominerese in tcrms of export. This makes sense because bringing products into outside markets is different from, for insrance, negotiating price-cost margins. Unlike the other proninence variables, the reversal of spillover direction is not observed for choice status, 
which suggests that dichotomizing volumes of inter-industry transactions may be too simplistic.

What is interesting about the seven range and brokerage variables is that five of them (contact efficjency; alter not work density; alter network proportional density; network constraint; and hicrarchy) are oegatively correlated whether significant or not with export, whereas only rwo (cgo-network size; and cffective size of ego-network) are positively correlared. This resulc is also expected from the variable descriptions. The negative coefficients for constraint and hierarchy variables are readily understoxd because, if an industry is severely constrained by its domestic transactions or, even worse, the sources of the constraint reduce to a handful of powertul industries, it would be hard for the industry to become internationally compritive. The negative coefficients for density variables indicate that an industry with high scores on these variables is just anorher member of a densely connected transaction clique, therefore, far from being strategic. Given these results, it is not easy to interpret the negative coefficients for contact efficiency variable because the negative coefficients for alter network density seemingly contradict the negative coefficients for contact efficiency. One interpretation might be that being a member of a "dense" network is different fron being a member of a "redundanc" network. A transaction network can be dense but still nut redundant. Although redundancy is often bad for the efficiency of information-garhering, it may rcpresent vertical linkages in transaction networks. Too much non-redundancy in the egometwork means that the positive spillover effect is disconnected after a very short path distance.

From the correlation berween network yariables and export performance, one would expect that $\mathrm{HCl}$, if strategic, have higher scores on prominence variables and two of the range and brokcrage variables (cyo-nctwork size; and effective size of ego-network) compared to non-HCIs. They should also have lowez scores on five of the range and brokerage variables (contact efficicocy; alter network density; proportional densiry of alter network: necwork constrainc; and hierarchy) relative to non-HCIs. In Table 3 , the mean scores of HCls generally behave as expected. Of the thirty variables (in terms of which the mean scores of HCIs and non-HCIs are compared), there are only five deviations: contact efficiency in both 1980 and 1940; upstream power in both 1980 and 1990; and downstream power in 1990. However, the mean power differences between HCIs and non-HCls are far from significant in both research years. Although the contact effeiency of HCls was significantly higher than non-HCls in 1980 , it does not bother us tow much because the correlation between contact efficiency and export was not significant in the same year. The only variable that pases a real problem is contact efficiency in 1990 because in this year, HCIs have on average significantly higher scores than non-HCIs on this variable which is negatively and significantly correlated with cxport. Ising network characteristics of an industry as the criteriva for straregie: valuc, it seems that industrics selected as FICIs are largely strategic for both years (with the exceprion of contact efficiency in 1990).

Now let us reverse the urder of reasoning to see if potentially strategic industries (in terms of their network position) have been selected as HCIs. For this purpose, we start with network variables having a significant correlation with export performance 
in Table 3, and find out whether HCls have a significant mean difference from non-HCIs with the expected direction of differences. Of the thirty variables in Table 3 , nineteen have a significant correlation with export performance (ego-network size, alter-network proportional density, upstream and downstrean choice scatus, and upstream and downstrearn extensive relations prominence for both years; effective cgo-network size, alter-nerwork density, network constraint, upstream exclusive relations prominence, and upsream power in 1980: contact efficicncy and downscream exchusive relations in 1990). Fleavy and Chemical Industries do not show a significantly different mean value from non-HCIs for eight out of these nineteen variables (upstream extensive relations prominence for both years; upstrcan exclusive relations prominence in 1980; upscream power in 1980; upstream choice status in 1990; downstreann extensive relations prominemce in 1990; downstran exclusive relations prominence in 1990 ; and alect-network proportional density in 1980$)$.

Two observations are woth mentioning from this partern. First, although "Big Push" took excellent advantage of strategic netwotk positions in terms of range and brokerage, it did less well in terms of prominence. Of the eight variables for which HCls do not show a significant difference from non-HCls, only one (alter-network proportional density in 1980 ) comes from the range and brokerage class. All the other seven variablcs are annong the prominence variables category. These are opportunities not taken advaritage of, and, therefore, wasted. Second, it stems that wasted opportunities are shifing from upstream to downstream. Of the seven wasted opportunities measured with prominence variables (three in 1980 and four in 1990), all three were upstream in 1980 and two out of four are donnstream is 1990. Recall once again that upstream opportunities arc created by a buyer induscry tor its supplier industries, and that downstream opportunities are created by a scticr industry for its buyer industries. 'The pattern suggests that in 1980 many of the ptominent buyer industries with their upstream, or backward-linkage. effects were not selected as HCIs, and, therefore, did not receive proper government support. In 1900 , some of the selter as well as the buyer industries were not selected as HCls. Judging from the exhaustive use of potential upportunities, "Big Push" does not scetn to have been a complete success

One final observation from Table 3 is that, alchough the absolute amount of $\mathrm{HCl}$ export has been increasing (Table 2), "Big Push" seetns to be becoming less effective in terms of the supporting industrics cccupying the strategic network positions. The corretation coefficients are either getting smaller in absoluce value (ego-network size from $.365^{* * *}$ to $.263^{* *}$; alter-network proportional density from $-.379^{* * *}$ to $-.303^{* * *}$; upstream choice status from $.239^{*}$ to $.221^{*}$; downstrearn choice status from $.338^{*}$ (0. $30 \mathrm{l}^{* * *}$; and upstream excensive relations prominence from $.499^{* * *}$ to $.248^{* *}$ ), or losing significance (effective ego-network size from $.273^{* *}$ to .149 ; alter-nctwork density from $-214^{*}$ to -.116 ; network constraint from $-.213^{*}$ to -.167 ; upstream exclusive relations prominence from.$\left\{27^{7 * *}\right.$ to .170 ; and upstram power from $.325^{\mathrm{k**}}$ to .138 ). There were only two variables that were not significant in 1980 but gained significance in 1990 (contact efficiency from -.140 to $-.306^{* * *}$; and downstream exclusive relations prominence from .123 to $.196^{\circ}$ ). 
Morc importantly, HCIs are losing more and more of their desirable network, hence spillover, characteristics. In 1980, HCIs had significant differences from non-HCIs as desired (i.e., significantly higher nean for variables with positive correlation for export, and a significantly lower mean for variables with negative correlation for export) for eighr (ego-network size; effective ego-network size; alter-network density; alter-nerwork proportional density; network constraint; upstrean and downstream choice status; and downstream extensive relations prominence) of the eleven variables that had a significant correlation with export. This number is decreased to only three in 1990 (ego-network size; alter-network proportional density; and downstream choice status). Heavy and Chemical Industries even have an undesirable network characteristic, such as high contact efficiency, in 1990. Using the correspondence of network characteristics of HCls and the corretation between thase charatcteristics and cxport, "Big Push" as a strategic industral policy is becoming obsolcte.

\section{INDUSTRY RESULTS: STRATEGIC INDUSTRIES, WRONG CHOICFS, AND WASTED OPPORTUNITIES}

This section examines the network analysis results at the level of individual industries rather than comparing the aggregate results of HCIs with non-HCIs, in order to find out which of the HCIs were indeed strategic or wrong choices, and, on the other hand, which potential opportunitics were wasted. Tables 4.1 chrough 4.3 show the list of industries that have significantly different values on the three classes of network variables: brokerage; upstream prominence; and downstream prominence. ${ }^{10}$

In each of the three tables, the upper-left cell contains strategically located industries that are HCls at the same time. The lower-right cell is of least interest because it represents poorly located industries that are not selected as HCIs. It is more interesting to see which industries appear in the lower-left and upper-right cells because they are wrong choices and wasted opportunities, respectively. in Table 4.1, it is remarkable that six of the fifteen HCIs in 1980 were indeed well-informed choices in terms of their ability as broker industries. Two $\mathrm{HCls}$ (chemical fiber; pig iron and steel), however, were wrong choices in both 1980 and 1990. Wasted opportunities exist in industries such as "fabricaced textile products," "miscellaneous manufacturing products," "transportation and warchousing, "building conscruction and repair," and "woud and wooden produces" in 1980 and "wholesale and retail trade," and "transportation and warehousing" in 1990. The six HCls that were highly strategic in 1980 are losing their stratcgic value in 1990.

\footnotetext{
17. The industries isted in Tables 4.1 through 4.3 are stected by the following coiteria. The anean value and standard deviarion are visculated for evesy wariable wirh significant correlarion with export. Industrics more than one standard deviation away from the mean in the desirable direction (i.e., above the mean

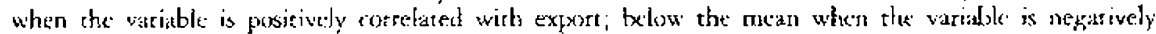
correlated with export) ard andesirable ditection (i.e., below the mean when the variable is positively correlaced with export; above the mean when the variable is negatively correlared with export are identified. (of these imciustries. only those appeared more than onie in the list are selected as eicher "strategicalky lowited (if they are in the desitable derectorn)" or "poorly located (if they are in the undesirable direction)." Hyorbeticat sectors and government sectors are deleted
} 
Tabif 4. I. Indoustries in Strategic or Poxor Brokerage Positjons

\begin{tabular}{|c|c|c|}
\hline & \multicolumn{2}{|c|}{1980} \\
\hline & HCIs & non-HCIs \\
\hline strategically loxared & $\begin{array}{l}\text { fabricated metal products } \\
\text { general nachinery } \\
\text { transportatius cquipnent } \\
\text { clectrical machincty } \\
\text { ronterrous metal prexducts } \\
\text { basic chemical products }\end{array}$ & $\begin{array}{l}\text { Fabricated textile products } \\
\text { miscellaneous manufacturing products } \\
\text { transportation \& warchousing } \\
\text { building construction \& repair } \\
\text { wood \& wooden products }\end{array}$ \\
\hline \multirow[t]{3}{*}{ poorly located } & $\begin{array}{l}\text { chemical fiber } \\
\text { pig iron and steel }\end{array}$ & $\begin{array}{l}\text { beavy construction } \\
\text { restaurants \& loxtging } \\
\text { tubacc) products } \\
\text { sugar manuficture } \\
\text { fishery products } \\
\text { metal ores } \\
\text { vegerables \& fruits } \\
\text { gas, sceidn, \& hot water supply } \\
\text { crops } \\
\text { crop milling. }\end{array}$ \\
\hline & \multicolumn{2}{|c|}{1990} \\
\hline & $\mathrm{HCls}$ & non-HCIs \\
\hline strategically located & & $\begin{array}{l}\text { wholesale \& retail crade } \\
\text { trarspurtation \& warchousing }\end{array}$ \\
\hline prorly located & $\begin{array}{l}\text { chemical fither } \\
\text { pig iron and steel }\end{array}$ & $\begin{array}{l}\text { agricultural services } \\
\text { restaurants \& lodging } \\
\text { metal ures } \\
\text { filct yarn } \\
\text { crude petrolecum \& natural gas }\end{array}$ \\
\hline
\end{tabular}

Comparing these tesults to the market structure maps in Figure 1 and Figuse 2, one can find that industries with high brokerage scores are clustered together around the center, while poorly located industries such as "chemical fiber" and "pig iron and steel" are near the periphery. The six HCIs that were highty strategic in 1980, and hence around the center of the map, generally moved toward the southeast corner in 1990. This is also consisten with the results in Table 3, where HCls lose part of their strategic value as broker industries by 1990 . Recall, however, that one of the main oricntations in the maps is given by the resnurce flow from the factor input sectors in the east to the final demand scctors of the west. Although this move of HCIs (from the center (i) the east) cost them their brokerage ability, it may have tendered them strategic in terms of downstream spillover effects.

In Table 4.2 , it is striking to find that none of the HCls were either strategically or poorly located in borh rescarch years, consistent with the results in Table 3 where IICls have a significantly different value from non-l ICls for only one (upstream choice status in 1980) of the cight variables measuring upstream prominence. In some cases, it is understandable because many $\mathrm{HCIs}$ ( $\epsilon . \mathrm{g}$. iron and steel market; chemical market) are upstream industries located toward the beginning of the chain of vertical inter-industry 
Tabie 4.2. Injujstries in Strategic on Poor upstream Prominence Positions

\begin{tabular}{|c|c|c|}
\hline & \multicolumn{2}{|c|}{1980} \\
\hline & HCIs & con-HCls \\
\hline strategrically lorared & & $\begin{array}{l}\text { commerce } \\
\text { building construction \& reapir } \\
\text { transportation \& warehousing } \\
\text { fabricated rextils: proxlucts } \\
\text { fiter yarn } \\
\text { dairy prexucts \& fruit processing }\end{array}$ \\
\hline \multirow[t]{3}{*}{ pexurly lecated } & & $\begin{array}{l}\text { sucial sctvices } \\
\text { fotestry products } \\
\text { water supply } \\
\text { gis, sceam, \& hot watce supply } \\
\text { nonmetallic minerals } \\
\text { precision instruments } \\
\text { sugar nanufacture } \\
\text { cash crop } \\
\text { flour } \\
\text { metal ores }\end{array}$ \\
\hline & \multicolumn{2}{|c|}{1940} \\
\hline & HCIs & non-HCIs \\
\hline \multicolumn{3}{|l|}{ strategically located } \\
\hline poorly located & & crude petroleum \& natural gas \\
\hline
\end{tabular}

Table 4.3. Inlutsines in Sthategic ok Pook downstrean Prominence Positions

\begin{tabular}{|c|c|c|}
\hline \multirow{3}{*}{ srrutegically located } & \multicolumn{2}{|c|}{1980} \\
\hline & $\mathrm{HCls}$ & mon-HCls \\
\hline & & $\begin{array}{l}\text { commerce } \\
\text { transportation \& warehousing }\end{array}$ \\
\hline \multirow[t]{3}{*}{ poorly locaced } & & gas, steam, \& hot water supply \\
\hline & \multicolumn{2}{|c|}{1990} \\
\hline & $\mathrm{HCls}$ & non-HCis \\
\hline strategically located & $\begin{array}{l}\text { petroleum refinery products } \\
\text { primitiry iron \& steel products } \\
\text { electronic componencs \& accessories } \\
\text { basic organic chemical products }\end{array}$ & $\begin{array}{l}\text { wholesale \& retail trade } \\
\text { funure \& insurance } \\
\text { transportarion \& warehousing } \\
\text { business services } \\
\text { clectric fower services } \\
\text { crops }\end{array}$ \\
\hline poorly located & & $\begin{array}{l}\text { tobacco products } \\
\text { proxessed seafoxit proklucts } \\
\text { agricultural services } \\
\text { wood furniture } \\
\text { social services }\end{array}$ \\
\hline
\end{tabular}


linkages. In other cases (e.g., machinery industries; electronic and transportarion equipment industries), however, the pattern suggests that necessary linkages between these industries and the supplier industries have been absent. It is likely that much of the upstream spillover generated by thesc industries has benefited expotters in other countries rather than the domestic suppliers. Again, there wert wasted opportunities in 1980 . Industries like "fabricated textile products," and "frber yarn" suggest dat rhese industries were nor only major exporters in the 1960)s and 1970s, but were still highly strategic in the 1980s. Indistries such as "building construction and repair," "transportation and warehousing," and "fabricated textile products" are worth special mention because they. are strategic in both brokerage and upstream prominence scores (see Table 4.1). In) Figute 1 , these industries tend to be located toward the western boundary of the intermediate sectors.

Table 4.3 probably gives the most interesting results. Desprite the fact that many HCIs were upstream industries with much downstream spillover, none of the HCls were strategic in 1980 . Four HCls have become strategic in terms of downstream spillover in 1990. This is a finding that the aggregate correlation cuefficients in Table 3 could not reveal. It is consistent, however, with the fact that HCIs have moved from around the cenret in the 1980 map to the southeast in the 1990 map (see Figures 1 and 2). This change signals that, although HCIs have failed ro establish upstream linkages (see Table 4.2), they are becoming more successful in establishing downstream linkages. There are wased opportunities in terms of downstream spillovers as well. The most obvious missed spprortunity lies in "tcansportation and warehousing," which is strategic in all three dimensions of industry network characteristics. The appearance of "finance and insurance" in 1990 secms to reflect the rapid axpansion of Kurea's financial sector since che introduction of financial liberalization policies in the early 1080s (Park 1994).

To summarize the industry-level analysis, the big trend is that $\mathrm{HCl}$ ate moving from important broker industries to important supplier (i.c., downstream-prominent) industries. This observarion is supported by these facts: none of the six HCIs that were highly strategic in brokerage ability in 1980 remained so in 1990 (Table 4.1); the mean differences of 1 iCls from rwn-HCJs on brokerage variables have become less significane in 1990 than they were in 1980 ( $\mathrm{Tuble}$ 3); while no $\mathrm{HCls}$ were strategic in downstream prominence in 1980. four are strategic in 1990 (Table 1.3); in terns of relative position in the market structure, HCIs have gencrally moved from around the center to the southeasterrs corner of the map (Figures 1 and 2).

There are other findings as well. Some of the opportunities (most obviously in industries such as "fabricated textilc products," "transportation and wasehousing," and "building construction and repair") are wasted. Many $\mathrm{HCls}$ do not have significantly different network diaracreristics from nom-HCIs. Two of the HCIs "chemical fiber" and "prig iron and steel" -..are wrong choices in terus of brokerage potential. They are isolated infustries whose transacrion profiles are not well mixed with those of the rest of the cconomy. Moreservice-oriented inclustries like "wholesale and retail," "finance and insurance." and "business services" are gaining in significance as supplier industries in 1990. 


\title{
VII. CONCLLSION: HOW STRATEGIC ARE S'TRATEGIC INDLS'TRIES?
}

In this final section, I briefly summarize what I consider the theoretical contributions of this paper, if any, and the major empirical findings. So far, the economic development literarure and nerwork theory have evolved independently of each orher. The main debare in the former has been the one between market advocates and statists, while the latter has largely been the realm of organization theorists. Yet, I suggest that the two branches of inquiry have much more in common than they seemingly do. For example, consider the following statcments by Evans (1979, 26):

\begin{abstract}
While the income from these few products is absolutely central to the process of accumulation in the dependent country, for the center each product represents only a tiny fraction of total imports, and carn usually be obtained from several different sources. 'The developinent of the dependent country, however, requires the continued acceptance of its products in the center. Therefore, economic fluctuations in the center may have severe negative consequences for the periphery, whereas an economic crisis in the periphery offers no real threat to accumulation in the center.
\end{abstract}

With the term "country" replaced by "organizations," it will not be easy to tell whether this paragraph is from Evans or Pfeffer and Salancik (1978). This obviously similar way of thinking tells us that there is much to be gained by bringing the theories and eechniques of network andysis into the development arena.

One such arena is the unsolved problem regarding the efficacy of state economic policy in the development of East Asian NICs, including Sourh Korea's "Big Push," where lietle atteneion has been paid to systematically investigating the strategic value of the so-called, "stratcgic industries." Although "strategic industry" is a key concept in the debate surrounding the rote of the market and the state of NIC's development, no one has ever tried to define the term in a specific way so that one can put it to an cmpirical rest. This paper aimed to do exactly this by bringing the network theory to define the various meanings of an industry's strategic value and analyaing the input-output tables of Korea for 1980 and 1990 .

The aggregate comparisons of $\mathrm{HCIs}$ with non-HCls provide four conclusions. First, if we usc export performance as the criterion of strategic industrics, HCIs were not strategic in 1980 and becoming to be so in 1990. Second, using the network, hence spillover, characteristics of IHCIs as the criterion, IXCls are largely scrategic in that the variables for which the IICls have a significantly different mean from non-HCIs have significast correlation with export in expected directions. Third, in terms of taking advantage of porential opporturities, "Big Push" was not a complete success for it failed to successfully cake advantage of the opportunities that were associated with prominent industries. Fourth, no mater what the level of strategic value of HCls in 1980. "Big Push" is becoming less effective in 1990 .

The industry-level analysis adds a few more observations to the above conclusions. 
While on the one hand HCIs are exporting significantly more in 1990 than they did in 1980, the meaning of their strategic value in the inter-industry transaction network, on the other, is changing from brokers to suppliers. These are some wrong choices and obviously wasted opportunities. In spite of their move from brokers to suppliers, HCIs have generally failed to establish backward, or upstream, linkages.

\section{REFERENCES}

Balassa, Bela and Associates. 1982. Development Strategies in Semi-industrial Economies. Baltimore, Md.: Johns Hopkins University Press for the World Bank.

Bank of Korea. 1991. Compilatory Report on 1990 Input-Output Table. Seoul: Bank of Korea.

Burt, Ronald S. 1988. "The Stability of American Markets." American Joumal of Swoiology: )1: $356-95$.

1992. Siructural Holes: The Saial Structure of Competition. Cambridge: Harvard University Press.

Burt, Ronald S. and Debsie Cardron. 1989. "Anocher Look at the Netwotk Boundaries of American Markets." American Joumal of Saciology: 95: 723-53.

Cole. David C. and Yung Chul Park. 1984. Finamial Development in Korea, 1945-80. Harvard University Press and Korea Development Institute.

Cho, Yoon Jc and Joon-Kyung Kim. 1995. "Credit Policies and the Industrialization of Korea." World Bank Discussion Paper. Washington D.C.: The World Bank.

Evans, Peter. 1979. Dependent Development: The Alliance of Multinational, State, and Loral Capital in Brazil. Princeton, N.J.: Princeton. University Press.

Freeman, Linton C. 1979. "Centrality in Social Necworks: Conceptual Clarification." Sxial Netuorks 1: 215-39.

Frieden, Jcrf. 1981. "Third World lndebeed Industrialization: International Finance and Scate Capitalism in Mexicu, Brazil, Algeria and Suuch Korea." Intemational Onganization 35: $107-31$.

Haggard, Stephan. 1990. Pathways from ibe Periphery. The Politics of Grouth in the Newly Industrializing Commies. Ithaca and London: Cornell Lniversity Press.

Johnson, Chalmers. 1982. MIT] and the Japanese Mirade; The Grouth of Industrial Policy. 1925-1975. Stanford, Calif: Stanford University Press.

1987. "Political Institutions and Economic Performance: The Government. Business Relationship in Japan, South Korea, and Taiwan." In The Political Economy of the Neut Asian Industrialism, ed. Fred C. Deyo. Ithaca and Iondon: Comell University Press.

Kavoussi, Rostam. 1985. "International Trade and Economic Developmenc: The Recent Experience of Developing Countries." Joumal of Detelofing Artas 19: 379-92.

Kim, Eun Mee. 1988. From Dominance to Symbiosis: State and Chaebol in Korea. Pacific Foras 3: $105-21$.

1997. Big Butsiness. Stmong State: Collusion and Conflit in Suuth Koneun Deveiopment, 1960-1990. New York: State Universiry of New York Press. 
Knoke, David and Ronald S. Burt. 1983. "Prominence." In Applied Network Analysis, ed. Ronald S. Burt and Michael J. Minor. Newbury Park, Calif.: Sage.

Lec, Ki-Yong. 19)4. Jongcbate Kumyzng Jedo Ui Hyonbruang, Hyokwa Bunsok Mit Katoson Banghyang [Policy laans: Cument Practick, Effects, and a Propersal for Improvement]. Seoul: Korea Tax Research Institure.

Leipziger, Danny M. 1987. Korea Managing the Industrial Transition, 2 volumes. Washington D.C.: The World Bank.

Leipziger, Danny M. and Peter A. Petri. 1993. "Korean Industrial Policy: Legacies of the Past and 1)irections for the Furure." Workd Bank Discussion Paper 197. Washington D.C.: The World Bank.

Luedde-Neurath, Richard. 1988. "State Intervention and Export-oriented Development in Sourh Korea." In Developmental States in East Asia, ed. Gordon White. Macmillan Press in association with the Institute of Development Studies, University of Sussex.

Michaely, Michael. 1977. "Export and Growth: An Empirical Investigation." Joumal of Deviopment Econmies 4: 19-53.

Park, Yung Chul. 1994. "Korea: Development and Structural Change of the Financial Syscem." In The Financial Develapment of Japan. Korea, and Taivian: Grouth. Repression, and Liberalization, ed. Hugh T. Patrick and Yung Chul Park. New York: Oxford University Press.

Pfeffer, Jeffrey and Gerald R. Salancik. 1978. The External Comtml of Organizations: A Resnurce Dependence Perspective. New York: Harper and Row.

Saxonhouse, Gary R 1983. "What is All This about 'Industrial Targecing' in Japan?" World Eirmmy (r: 253.73.

Schore, Thomas. 1991. "Nerwork Models." In Struture Version 4.2 Reference Mannal. New York: Center for the Social Sciences, Columbia University.

Singer, Hans W. and Patricia Gray, 1988. "Trade Policy and Growch of Developing Councries: Some New Data." World Dexilopment 16: 395-403.

Wade, Robers. 1990. Ginerning the Market: Econtmic Theory and the Role of Gervermment in East Ajian Indhistrialization. Princeton, N.J.: Princeton Universiry Press.

Wassennas, Stanley and Katherine Faust. 1994. Social Network Anulyis: Methods and Applications. Cambridge: Cambridge University Press.

Woo, Jung-En. 1991. Rate to the Swift: State and Finance in Koran Indistrialization. New York: Columbia University Press.

The World Bank. 1993. The East Asian Miracle: Economic Gmoth and Public Policy. Oxford University Press for the World Bank.

Woronoff, Jon. 1992. Jatpancse Targeting: Successes, Failarei, and Tessons. New York: St. Martin's Press. 